\title{
Influence of bamboo dieback on arboreal diversity in a subtropical forest fragment
}

\author{
Elivane Salete Capellesso ${ }^{1 *}$, Rafael Weirich ${ }^{1}$, Giamarco Dariva ${ }^{1}$, Tanise Luisa Sausen ${ }^{2}$ and Elisabete Maria Zanin ${ }^{3}$
}

\begin{abstract}
Background: The vegetation structure and dynamics in subtropical forest fragments is influenced by the bamboo density. After the reproductive events followed by the death of the bamboos, is critical to understanding community structure and regeneration processes over time. The aim of this study was to evaluate temporally the influence of height and density of Merostachys multiramea on the richness, density and diversity of tree species after the event of bamboo dieback. The study was conducted in subtropical forest in southern Brazil, characterized by intense fragmentation of habitats, which facilitates the establishment of bamboo species.

Results: We observed an increase in bamboo height over time, as well as an increase in the number of individuals between the fourth and sixth years of study. The number of $M$. multiramea individuals did not influence the density of regenerated individuals, but residuals analysis for estimated species richness showed the influence of bamboo on regeneration process. Six year after the bamboos death we observed a higher similarity in density of individuals between the sampling units.

Conclusions: The results of this study demonstrated distinct phytosociological structures during the different years of study, indicating that six years after the bamboos death, the vegetation structure has a higher similarity in the evaluated forest fragments in Southern Brazil, indicating a possible stabilization in the forest structure.
\end{abstract}

Keywords: Merostachys multiramea, Regeneration dynamic, Gaps, Forest structure, Seedlings

\section{Background}

In native forests, the gaps formations in the forest structure that arise from bamboo dieback characterize an environmental disturbance, which has a direct influence on the initial process of regeneration [1, 2]. Bamboo dieback is an important small-scale dynamic process in forest renovation, because it influences the germination rate, mortality and the development of forest species [3], increases tree species richness [4], and is associated with changes in environmental conditions, especially in light and temperature [5].

Merostachys multiramea Hack. is a south Brazil native species of bamboo, which displays cyclical and massive flowering every 31-33 years [6]. The last reproductive event in a subtropical forest in southern Brazil was observed between 2006 and 2008 [7]. Following bamboo dieback, the formation of gaps of different sizes was observed within the forest, which had a direct effect on the

\footnotetext{
* Correspondence: elivanesc@gmail.com

${ }^{1}$ Ecology Post-Graduate Program, Universidade Regional Integrada do Alto Uruguai e das Missões - URI, Av. Sete de Setembro 1621, Erechim, RS, Brasil Full list of author information is available at the end of the article
}

light intensity reaching the forest understory and on temperature [5], which influences the regeneration of tree seedlings $[5,8,9]$.

Bamboo dieback events are responsible for alterations in the availability of resources within a few years, and they promote the development of individuals that are already established, and the establishment of new individuals in formed clearings $[1,10]$. The presence of bamboo has a direct effect on the dynamics of native species [7]; furthermore, death of bamboos modifies environmental conditions and affects the process of forest regeneration [5]. Studies that have taken a temporal approach to the natural regeneration process following bamboo dieback events are extremely important to understand the processes of dynamic competition and the long-term structure of subtropical forests.

The aims of this study were to evaluate the temporal variation, and the influence of height and density of $M$. multiramea on the richness and density of tree species, and to monitor whether clearings influence tree regeneration and the establishment of M. multiramea. We 
expect that as M. multiramea increase in density and height, tree species richness decrease, creating a distinct forest structure over the years.

\section{Methods}

\section{Study area and data collection}

This study, performed in area of subtropical forests in Southern Brazil (Fig. 1), began in 2008, two years after bamboo flowering and fruiting, followed by death and fall. For the study design, 25 sampling units of $10 \times 10 \mathrm{~m}$ were demarcated. The description of the abiotic conditions in the study areas after the M. multiramea reproductive event followed by death and fall can be found at Budke et al. [5].

This study consisted of surveys conducted in 2008 [5], 2010 [7] and in 2012, which corresponded to two, four and six years after $M$. multiramea dieback occurred in 2006. All surveys evaluated tree regeneration between $30 \mathrm{~cm}$ to $1 \mathrm{~m}$ in height, including tree diameter at soil level and height. To measure the density of $M$. multiramea, we measured the number of individuals and their height.

\section{Data analysis}

To evaluate the differences in the bamboo density and height between years, we performed a one-way analysis of variance (ANOVA) for the individual's number and height between years of the study, 2008, 2010 and 2012.

We obtained the structural variables of the tree regeneration component in all sample units, including individual density, species richness, Shannon diversity and Pielou equability. To evaluate the differences between years, a one-way ANOVA were performed. To assess similarity in density of individuals between sample units, we calculated the Bray-Curtis similarity index, within and between different surveys, followed by Principal Coordinate Analysis ( $\mathrm{PCoA}$ ), by visually comparing the similarity between the surveys.

The relationship between density of seedlings of tree species and that of M. multiramea Hack. was evaluated by linear regression. We used the residuals of this analysis to perform another linear regression, with species richness as the dependent variable, thus eliminating the effect of the density of tree regeneration on the observed richness. All analyses were performed using PAST [11].

\section{Results}

Relationship between plant density and the height of $M$. multiramea over time

The density of M. multiramea Hack. increased in the period between two and four years, followed by a decline after six years (Fig. 2), after the reproductive event. We

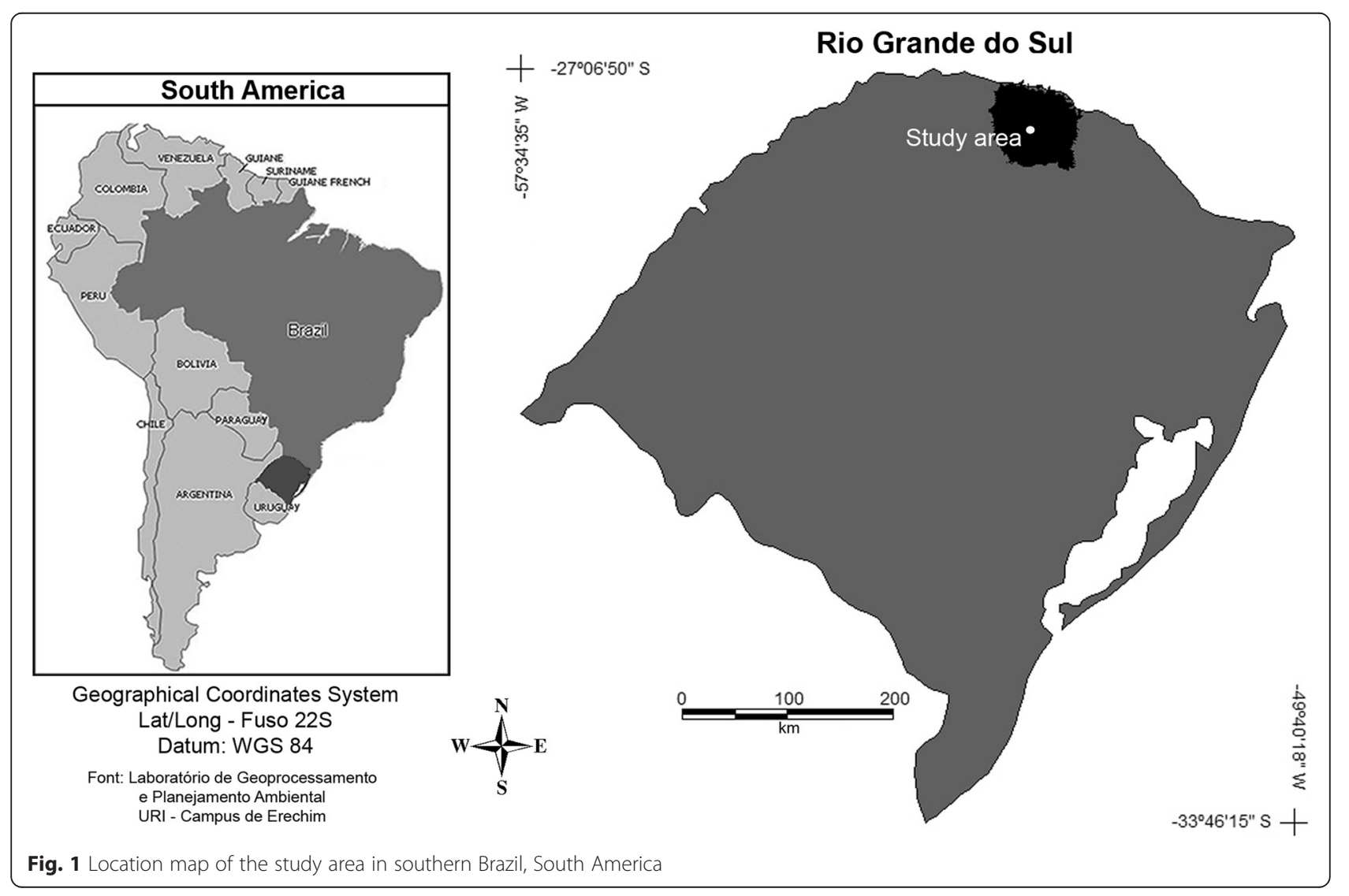



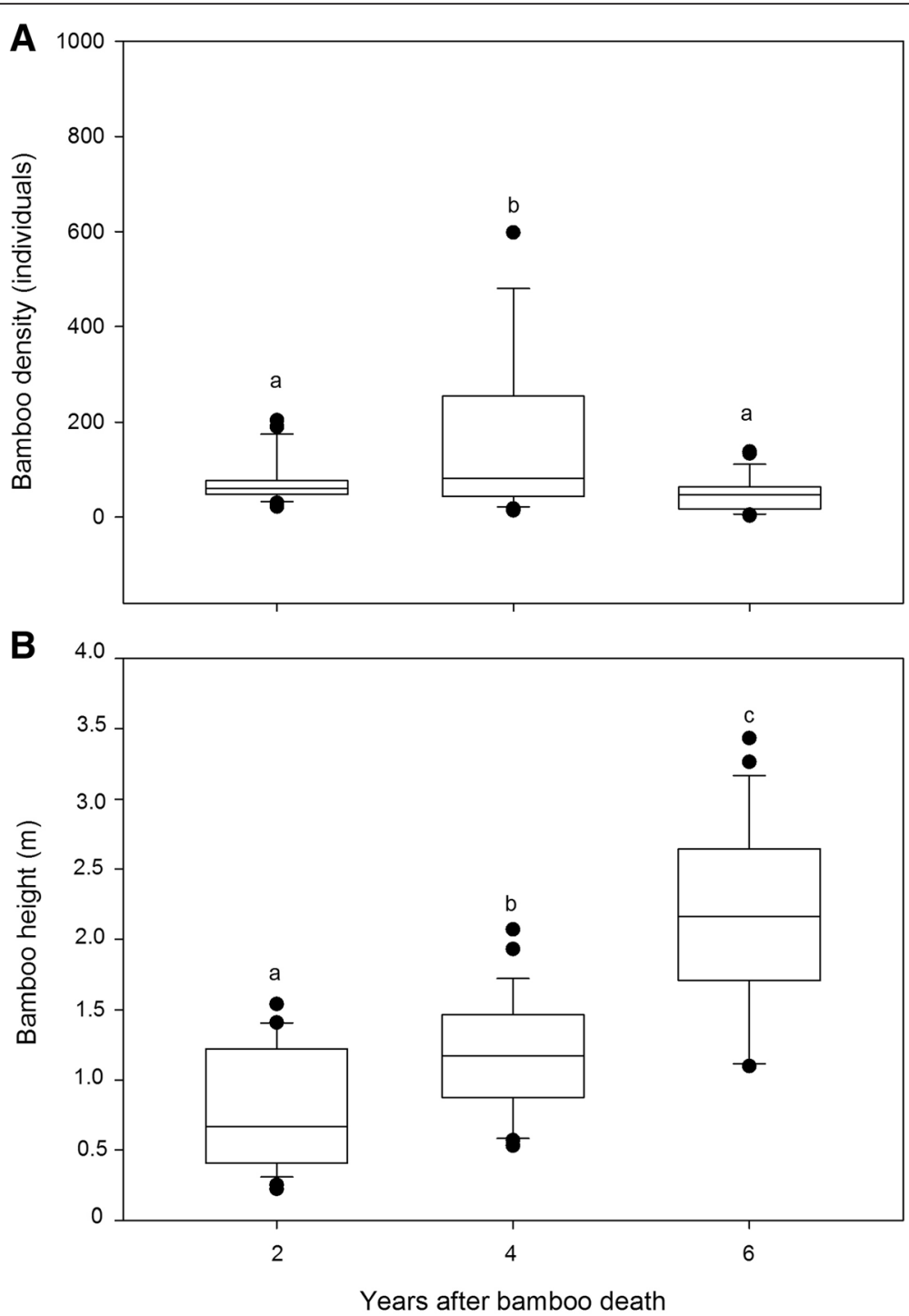

Fig. $\mathbf{2}$ a Density of Merostachys multiramea and $\mathbf{b}$ Height of Merostachys multiramea after two, four and six years of bamboo death

observed differences in density between four and six years after the reproductive event. Height of M. multiramea individuals progressively increased over the time, with 2012 being significantly different from that in other years $(F=254, \mathrm{df}=2, p \leq 0.001)$.

\section{Temporal variation and the influence of $M$. multiramea richness and tree density}

We observed a difference in the density of individuals of tree species after six years of study, differing from second and fourth years (Table 1). The richness of species remained stable throughout the study period. The second year of study showed a higher diversity, followed by the fourth year and the sixth year (Table 1).

We did not observe significant relationship between density of tree seedlings and density of $M$. multiramea
Hack. $\left(R^{2}=0.01, p=0.53\right)$ (Fig. 3a). However, the analysis of residues revealed a positive linear relationship with the estimated species richness $\left(R^{2}=0.17, p=0.035\right)$ (Fig. 3b).

\section{Forest structure after bamboo dieback}

Six years after $M$. multiramea reproductive event and dieback, we observed differences between species composition and their respective density, demonstrating distinct phytosociological structures during the different years of study (Fig. 4). After two and four years of study was observed a superposition of sample units indicating a vegetation structural similarity in the 2008 and 2010 surveys after the death of $M$. multiramea. However, the sample units corresponding to six years were different from previous assessments (2008 and 2010) and demonstrated 
Table 1 Tree species richness, density of tree seedlings, diversity and equitability observed after two, four and six years of bamboo death in a subtropical forest in Southern Brazil

\begin{tabular}{llll}
\hline & $2 y$ & $4 y$ & $6 y$ \\
\hline Species richness & $56 \mathrm{ab}$ & $64 \mathrm{a}$ & $62 \mathrm{~b}$ \\
Density of tree seedlings & $1446 \mathrm{a}$ & $1188 \mathrm{a}$ & $3117 \mathrm{~b}$ \\
Shannon diversity $\left(\mathrm{H}^{\prime}\right)$ & 2.61 & 2.42 & 2.13 \\
Pielou equability $\left(\mathrm{J}^{\prime}\right)$ & 0.64 & 0.58 & 0.51 \\
\hline
\end{tabular}

Different letters indicate differences between areas and years
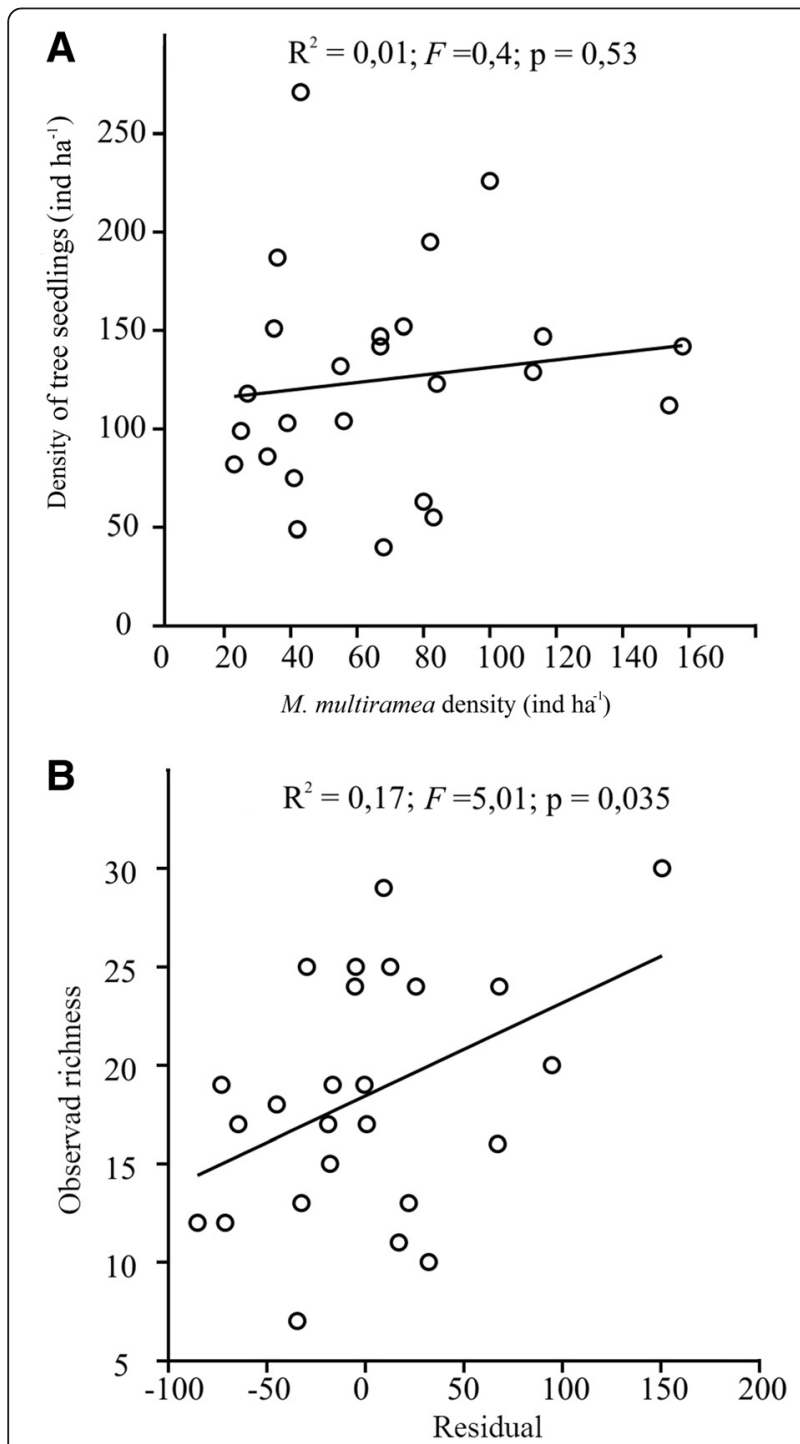

Fig. 3 a Regression analysis between the density of Merostachys multiramea and the density of tree seedlings; $\mathbf{b}$ regression analysis between their residual and species richness observed between samples units surveys conducted six years after the bamboo death an overlap, indicating that in 2012, sample units have a similar vegetation structure.

\section{Discussion}

We expected that $M$. multiramea Hack. would show an increase in number and height of individuals, but this pattern was observed only for height throughout the study, with the number of individuals decreased over the years of the study. The vegetation structure did not change in the first four years (2010) after the death and clearing of $M$. multiramea, partially contradicting the hypothesis of this study. We expected that species richness would decrease with time. Differences in the composition and density of species were already observed six years after the death and clearing of bamboo (in 2012). This structural variation only in the last survey might be associated with the process of stabilization between bamboo and the forest vegetation in the study area. This hypothesis is supported by Taylor et al. [12], who state that the dead bamboo stalks remain in the area for 3-6 years, which ultimately inhibits seedling establishment. The responses of vegetation after the death and clearing of bamboo represent a continuous process and therefore, should be studied for many years [13]. Muñoz and Gonzáles [14], Montti et al. [9] and Muñoz et al. [15] observed that the positive effects of death of bamboo on tree regeneration are restricted to a short period of time, and other environmental factors might be associated with the temporal pattern of regeneration.

The height increment of bamboos might have caused partial or total closure of the gaps formed after death and clearing of bamboo, affecting light conditions and temperature, which can positively influence the regeneration process. The increased height of individuals of M. multiramea was associated with an increase in the density of regenerating tree individuals. Additionally, Campanello et al. [8] reported that woody invasion might increase after the death of bamboo, since the opening of gaps caused by bamboo dieback causes changes in the area microclimate, which plays a major role in establishment, development and reproduction in natural environments [5, 16]. However, Montti et al. [17] observed that the increase in height in two species of bamboo negatively affected the survival of tree species in the cleared areas.

The increase in the density of bamboo was directly associated with the decrease in the density and density of individual trees, due to competition with the tree species [13]. Following the decrease in the density of bamboo, tree regeneration increased, as was observed after six years of study. Species richness did not change throughout the study, similar to the findings of Montti et al. [9], studying the dynamics of Chusquea ramosissima in an Argentinian forest. Regression analysis showed no 


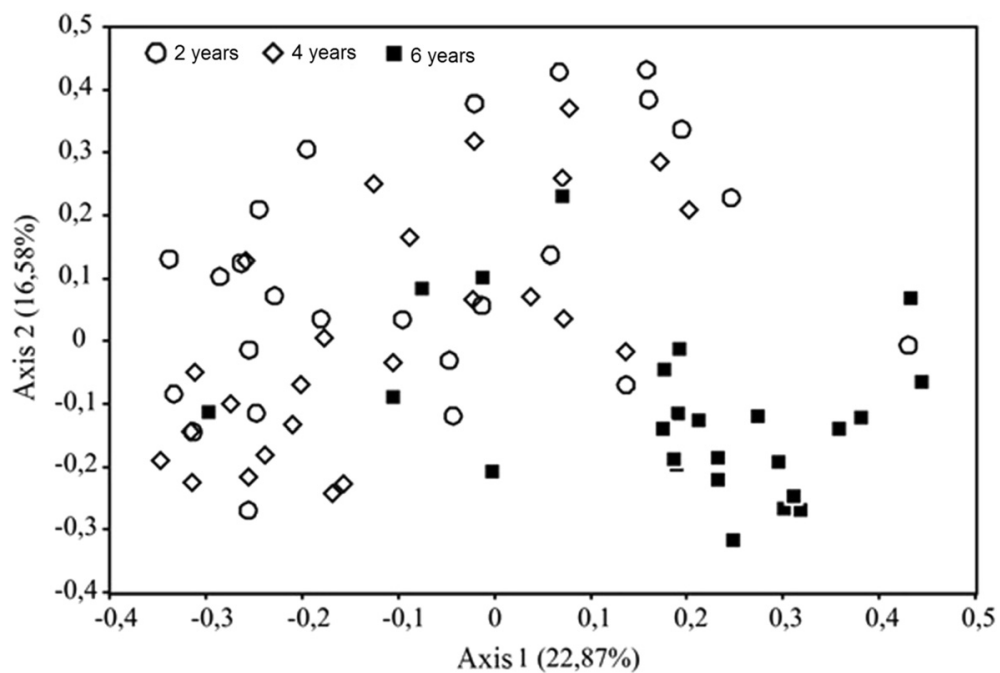

Fig. 4 Principal Coordinates Analysis (PCOA) between samples units surveys of tree regeneration performed two, four and six years after the Merostachys multiramea death

significant relationship between density of tree species and density of $M$. multiramea Hack. However, analysis of residual revealed a negative relationship between the density of $M$. multiramea and species richness, indicating an effect of bamboo on the vegetation structure.

The diversity index assessed in this study demonstrated a reduction in diversity over time, corroborating the results of Holz and Veblen [13], performed on the border between Chile and Argentina. This temporal reduction in diversity might be directly related to variations in environmental conditions associated with the gaps caused by M. multiramea dieback. Following bamboo dieback, more light can provide more suitable conditions for germination and seedling banks, maintaining their presence in the area. However, Montti et al. [17] suggest that reducing the diversity, to encourage successful growth of tree species after flowering bamboo, appears to be related to a very narrow window during which individuals that are already established can survive and use the very few resources associated with the opening of the gap.

The results of this study indicated that temporal variation in abundance and height of $M$. multiramea influences the vegetation structure in subtropical forest fragments, with a distinct vegetation structure over the years. The abundance and richness of tree species sampled in the first evaluations (2008 and 2010) suggests that the bamboo death provides abiotic conditions that facilitate to germination of seeds in soil bank bank and seedling establishment. Budke et al. [5], two years after the death of $M$. multiramea, observed a positive relationship between trees density with moisture, and negative with the opening canopy. The higher canopy openness after the death of $M$. multiramea was associated with the establishment, mainly of pioneer species such as Cupania vernalis Cambess., Sebastiania brasiliensis Spreng., Dalbergia frutesens (Vell.) Britton e Calyptranthes concinna DC.

Additionally, it can be inferred that the wide variation observed in the abundance of tree species between two to six years, can be associated with the presence of certain species with a high individual density, especially four years after the bamboos death. In this context there are the species Actinostemon concolor Spreng., Pilocarpus pennatifolius Lem. and Trichilia elegans A. Juss., characterized by high establishment rate in study areas and shade tolerance. Thus, similar vegetation structure observed after six years (2012) it was caused by high density of shade tolerant species, features of understory and dependent on the establishment and growth of $M$. multiramea individuals.

\section{Conclusions}

We can conclude that the disturbance caused by the death and clearing of bamboo, leading to the opening of gaps, is responsible for changes in the environment, and influences the growth of $M$. multiramea and the tree species, with a marked temporal pattern. The increase in height of individuals of $M$. multiramea is responsible for changes in the environmental conditions in the understory, and characterizes a process of competition for space, which does reduce the establishment of some species. However, due to a reduction in the density of bamboo over time and a consequent reduction in the competition for space, the density of regenerating individuals increases significantly, independent of the bamboo height, and is responsible for the observed differences in vegetation structure in subtropical forests dominated by bamboo. 


\section{Competing interests}

The authors declare that they have no competing interests.

\section{Authors' contributions}

ESC carried out in the sample design, participated in sampling, data analysis and drafted the manuscript. GD and RW participated in sampling and data analysis. TLS and EMZ participated in drafted the manuscript. All authors read and approved the final manuscript.

\section{Acknowledgement}

The authors thanks to the "Programa de Pós-Graduação em Ecologia" and to the Department of Biological Sciences of Universidade Regional Integrada do Alto Uruguai e das Missões -URI for financial support to our study.

\section{Author details}

'Ecology Post-Graduate Program, Universidade Regional Integrada do Alto Uruguai e das Missões - URI, Av. Sete de Setembro 1621, Erechim, RS, Brasil. ${ }^{2}$ Plant Ecology and Systematics Laboratory - ECOSSIS, Universidade Regional Integrada do Alto Uruguai e das Missões - URI, Av. Sete de Setembro 1621 , Erechim, RS, Brasil. ${ }^{3}$ Geoprocessing and Environmental Planning Laboratory, Universidade Regional Integrada do Alto Uruguai e das Missões - URI, Av. Sete de Setembro 1621, 99700-000 Erechim, RS, Brazil.

\section{Received: 25 August 2015 Accepted: 10 February 2016}

\section{Published online: 08 March 2016}

\section{References}

1. González ME, Veblen TT, Donoso C, Valeria L. Tree regeneration responses in a lowland Nothofagus-dominated forest after bamboo dieback in southcentral Chile. Plant Ecol. 2002:161:59-73.

2. Rother DC, Rodrigues RR, Pizo MA. Effects of bamboo stands on seed rain and seed limitation in a rainforest. Forest Ecol Manag. 2009;257:252-63.

3. Whitmore TC. Canopy gaps and the two major groups of forest tree. Ecology. 1989;70:536-8.

4. Brokaw N, Busing RT. Niche versus chance and tree diversity in forest gaps. Tree. 2000:15:375-6.

5. Budke JC, Alberti MA, Zanardi C, Baratto C, Zanin EM. Bamboo dieback and tree regeneration responses in a subtropical forest of South America. Forest Ecol Manag. 2010;260:1345-9.

6. Schmitt R, Longhi-Wagner HM. A tribo bambuseae (Poaceae: Bambusoideae) no Rio Grande do Sul, Brasil. Braz J Biosci. 2009;7:71-128.

7. Santos SC, Budke JC, Muller A. Regeneração de espécies arbóreas sob a influência de Merostachys multiramea Hack. (Poaceae) em uma floresta subtropical. Acta Bot Bras. 2012;26:252-63.

8. Campanello PI, Gatti MG, Ares A, Montti L, Goldstein G. Tree regeneration and microclimate in a liana and bamboo-dominated semideciduous Atlantic Forest. Forest Ecol Manag. 2007:252:108-17.

9. Montti L, Campanello PI, Gatti MG, Blundo C, Austin AT, Sala OE, Goldstein G. Understory bamboo flowering provides a very narrow light window of opportunity for canopy-tree recruitment in a neotropical forest of Missiones, Argentina. Forest Ecol Manag. 2011;262:1360-9.

10. Giordano CV, Sánchez RA, Austin AT. Gregarious bamboo flowering opens a window of opportunity for regeneration in a temperate forest of Patagonia. New Phytol. 2009;181:880-9.

11. Hammer $\varnothing$, Harper DAT, Ryan PD. PAST: paleontological statistics software package for education and data analysis. Palaeontol Electron. 2001:4:9.

12. Taylor AH, Jinyan $H$, Shiquiang Z. Canopy tree development and undergrowth bamboo dynamics in old-growth Abies-Betula forests in southwestern China: a 12-year study. Forest Ecol Manag. 2004;200:347-60.

13. Holz CA, Veblen TT. Tree regeneration responses to Chusquea montana bamboo die-off in a subalpine Nothofagus forest in the southern Andes. J Veg Sci. 2006;17:19-28.

14. Muñoz AA, Gonzáles ME. Patrones de regeneración arbórea en claros a una década de la floración y muerte masiva de Chusquea quila (Poaceae) en un remanente de bosque antiguo del valle central en el centro-sur de Chile. Rev Chil Hist Nat. 2009;82:185-98.

15. Muñoz AA, Gonzáles ME, Celedón C, Veblen TT. Respuesta inicial de la regeneración arbórea luego de la floración y muerte de Chusquea culeou (Poaceae) en bosques andinos del centro-sur de Chile. Bosque. 2012;33(2): 153-62
16. Martins SV, Rodrigues RR. Gap-phase regeneration in a semideciduous mesophytic forest, south-eastern Brazil. Plant Ecol. 2002;163:51-62.

17. Montti L, Villagra M, Campanello PI, Gatti MG, Goldstein G. Functional traits enhance invasiveness of bamboos over co-occurring tree saplings in the semideciduous Atlantic Forest. Acta Oecol. 2013;54:1-9.

\section{Submit your next manuscript to BioMed Central and we will help you at every step:}

- We accept pre-submission inquiries

- Our selector tool helps you to find the most relevant journal

- We provide round the clock customer support

- Convenient online submission

- Thorough peer review

- Inclusion in PubMed and all major indexing services

- Maximum visibility for your research

Submit your manuscript at www.biomedcentral.com/submit
C Biomed Central 